\title{
DETERMINATION OF THE EFFECT OF PLANT GROWTH PROMOTING BACTERIA ON WHEAT (TRITICUM AESTIVUM L.) DEVELOPMENT UNDER SALINITY STRESS CONDITIONS
}

\author{
SÖĞÜT, S. - ÇıĞ, F. ${ }^{*}$ \\ Department of Field Crops, Faculty of Agriculture, Siirt University, Siirt, Turkey \\ *Corresponding author \\ e-mail:fatihcig@hotmail.com; phone: +90-533-777-1140 \\ (Received 20 $0^{\text {th }}$ Sep 2018; accepted $2^{\text {nd }}$ Jan 2019)
}

\begin{abstract}
This study was carried out in Field Crops Department Laboratory of Siirt University, Faculty of Agriculture (Turkey) in 2016. In the study, Ceyhan 99 bread wheat cultivar was used. It was aimed to determine the effect of TV14B Stenotrophpmonas maltophilia P (phosphate solubilizing bacteria), TV119E Bacillus-GC group P (phosphate solubilizing bacteria), TV83D Bacillus atrophaeus $\mathrm{N}$ (nitrogen fixing bacteria), TV54A Cellulomonas turbata N (nitrogen fixing bacteria), TV113C Kluyvera cryocrescens NP (nitrogen fixing + phosphate solubilizing bacteria), TV83D B. atrophaeus + TV119E Bacillus-GC group (binary combination) bacterial strains on development of Ceyhan-99 bread wheat cultivar under salinity stress. The germination rate $(\%)$, germination percentage $(\%)$, plant height $(\mathrm{cm})$, root length $(\mathrm{cm})$, plant wet weight $(\mathrm{g})$, plant dry weight $(\mathrm{g})$, nitrogen amount in the soil $(\%)$ and phosphorus amount in the soil (\%) were determined with the test conducted. It is concluded that TV14B $S$. maltophilia $\mathrm{P}$ bacteria had positive impacts on plant growth parameters at different salinity concentrations. It was observed that TV119E Bacillus-GC group P bacteria, in $100 \mathrm{mM}$ salt concentration, increased plant height, phosphorus in the soil and dry weight parameters. TV83D $B$. atrophaeus $\mathrm{N}$ bacteria treatment in $125 \mathrm{mM}$ salt concentration increased root length, phosphorus and nitrogen amount in the soil compared to the control treatment. It was observed that treatments of TV54A C. turbata N, TV113C $K$. cryocrescens NP and TV83D B. atrophaeus +TV119E Bacillus-GC group NP bacteria in different salt concentrations increased both phosphorus and nitrogen amounts in the soil. As a result, these bacteria treatments were considered to alleviate the disadvantages of salinity stress.
\end{abstract}

Keywords: biofertilizer, biotic stress, salt concentrations, yield, yield elements

\section{Introduction}

Cereals are the plant group with the highest cultivation and yield amounts. Almost half of the Earth's 1.4 billion hectares of cultivated land is used for cereal cultivation. Cool season cereals are cultivated in $49.5 \%$ of the land used for cereal cultivation in the world. The rapid increase in the world population and steady development of living standards made it necessary to obtain higher yields in agricultural production, which is an important source for human nutrition. For this reason, the concept of soil fertility gained importance and became a hot topic. One of the most effective means of increasing the unit area productivity is usage of chemical fertilizers. It is stated that, despite the varying production conditions, share of fertilizers in yield increase is approximately $50 \%$ (Aydeniz, 1992). A significant amount of nitrogen and phosphorus is being removed from soil through surface runoff and drainage waters due to incorrect and excessive fertilizer usage (Guttman, 1999). This leads to an increase in the nitrate concentration in drinking water reserves and in leaf vegetables, as well as forage crops, which adversely affects the health of the animals fed with these feed crops (Abdel et al., 1997).

Tough, the bacteria known as biological fertilizer and promoting plant growth gradually increase their place in the studies on production of biological preparations, 
with their positive effects on plant growth and systemic resistance (Upadhyay et al., 2014; Ansari and Ahmad, 2018).

Recognition of potential damages given by the chemical inputs, used to increase quality and yield in agricultural production, in the long term resulted in a quest for alternative solutions. Approaches such as "Organic Agriculture", "Integrated Pest Management" and "Good Agricultural Practices" aim at minimizing the amount of synthetic inputs. Plant Growth Promoting Rhizobacteria (PGPR) are getting more attention in the studies on biological preparations due to their positive effects on plant growth and systemic resistance.

Ceyhan- 99 wheat variety by superior adaptability, efficiency and quality is one of the most cultivated varieties of bread wheat in Turkey and has the potential to also be trained in a similar ecological conditions world. There has not been any study on the resistance to salinity with PGPR application before. Therefore, the development of PGPR application with Ceyhan-99 wheat varieties was discussed.

In this study, effects of microorganisms on growth and development of wheat under salinity stress were examined by using nitrogen fixing and phosphate solubilizing bacteria as biological fertilizer elements, in order to avoid the environmental and human health threats posed by inorganic fertilizers (Shrivastava and Kumar, 2015; Hashem et al., 2016).

\section{Literature review}

Several studies have been carried out in many countries on the effects of Plant Growth Promoting Rhizobacteria (PGPR) on yield increase (Chen et al., 1996; Luz, 2000; Romerio, 2000; Wall, 2000). Although the positive impacts of PGPR on plant development have not been fully explained, it is known that these bacteria can produce plant hormones such as auxin (Jeon et al., 2003; Aslantaş et al., 2007; Sabır, 2013), cytokinin (García de Salamone et al., 2001), gibberellin (Gutiérrez-Mañero et al., 2001) and ethylen (Glick et al., 1995); fixate asymbiotic nitrogen (N) (Şahin et al., 2004); dissolve mineral phosphate $(\mathrm{P})$; mineralize organic phosphate and other nutrients (Jeon et al., 2003; Canbolat et al., 2006); show antagonistic impact on pathogens by synthesizing siderophore, antibiotics, enzyme and fungicide compounds or via competition (Dey et al., 2004).

The use of bacteria in agriculture as biofuels or control agents has increased since 1990s. In recent years, the scope of biological fertilization has extended to include free living rhizobacteria usage as plant growth promoter, biological control agent or biofertilizer.

Öztürk et al. (2003) analysed the impacts of inoculating plant growth promoting bacteria on wheat and barley yield at three different nitrogen fertilization levels. It was shown that inoculation of the seeds with Azospirillum brasilense Sp246 has significant impacts on the yield and yield elements. It was reported in the study that Azospirillum brasilense Sp246 has the potential to be used as biological fertilizer in summer wheat and barley cultivation in organic and good agricultural practices. Çakmakçı et al. (2007) stated that inoculation of Bacillus RC01, Bacillus M-13, Bacillus RC02, Rhodobacter RC04, Paenibacillus RC05, Pseudomonas RC06 and Bacillus OSU-142 bacteria isolated from the roots of wheat and barley increases barley root weight by $21.4 \%, 17.9 \%$, $25.0 \%, 21.4 \%, 28.6 \%, 21.4 \%$ and $32.1 \%$ and body weight by $39.0 \%, 30.5 \%, 28.8 \%$, $32.2 \%, 54.2 \%, 32.2 \%$ and $47.6 \%$, respectively. They argue that these strains have 
significant potential to be used as biological fertilizers. Narula et al. (2005) isolated and identified diazotrophs that fixate nitrogen and produce plant hormones such as azotobacter and used these as biological fertilizers with different nitrogen dosages on wheat and cotton plants under field conditions. They observed significant impacts on wheat using biological inoculants. The researchers showed that the impact of biological inoculants are more visible in the second year, as the inoculator amount is maintained in the soil. Furthermore, when appropriate biological fertilizers are used, $25-30 \mathrm{~kg}$ of nitrogen can be saved in wheat cultivation. Salantur et al. (2006) studied the impacts of root bacteria inoculation on growth and yield of summer wheat under greenhouse and field conditions. The results of greenhouse trials showed that the bacteria have positive and significant impact on the number of tillers, plant length, dry matter and protein content of the plant. It was presented that the root bacteria inoculated in wheat increased the growth, kernel yield and $\mathrm{N}$ content under field conditions.

\section{Materials and methods}

\section{Materials}

Wheat (Ceyhan-99)

Ceyhan-99 bread wheat cultivar was used in the study. This cultivar has a height of 90 to $100 \mathrm{~cm}$. The plant is resistant to lodging and has white-spined spike structure. Spikes are upright with medium length. The grains are oval, hard, white colour and thousand grains weight has 42 to $45 \mathrm{~g}$. The cultivar is moderately resistant to winter and drought and its fertilizer reaction and harvesting-threshing ability is good.

\section{Bacteria strains}

The bacteria inoculated in wheat are Stenotrophpmonas maltophilia $\mathrm{P}$ (phosphate solubilizing bacteria) TV14B, Bacillus sp. P (phosphate solubilizing bacteria) TV119E, Bacillus atrophaeus $\mathrm{N}$ (nitrogen fixing bacteria) TV83D, Cellulomonas turbata $\mathrm{N}$ (nitrogen fixing bacteria) TV54A, Kluyvera cryocrescens NP (nitrogen fixing + phosphate solubilizing bacteria) TV113C, B. atrophaeus + Bacillus sp. (binary combination) TV83D + TV119E and they were isolated from Van Lake Basin. The strains were identified in Bacteriology Laboratory of Atatürk University Faculty of Agriculture Department of Field Crops and the impacts of PGPR tested under greenhouse and field conditions.

\section{Soil properties}

Some soil properties were determined as neutral in terms of $\mathrm{pH}$, saltless, low in organic matter and lime, insufficient phosphorus, sufficient and more potassium, iron, manganese and copper, deficiency in zinc (Table 1).

Table 1. Some properties of experimental soil

\begin{tabular}{c|c|c|c|c|c|c|c|c|c|c|c|c|c}
\hline $\mathbf{p H}$ & $\begin{array}{c}\mathbf{E c} \\
\mathbf{d s} / \mathbf{m}\end{array}$ & $\begin{array}{c}\text { Lime } \\
\mathbf{C a C O} \\
\mathbf{\%}\end{array}$ & $\begin{array}{c}\text { Organic } \\
\text { matter } \\
\mathbf{\%}\end{array}$ & $\begin{array}{c}\text { Phosphorus } \\
\mathbf{P}_{2} \mathbf{O}_{5} \\
\mathbf{k g} / \mathbf{d a}\end{array}$ & $\begin{array}{c}\text { Potassium } \\
\mathbf{K} \mathbf{O} \\
\mathbf{k g} / \mathbf{d a}\end{array}$ & $\begin{array}{c}\mathbf{F e} \\
\mathbf{p p m}\end{array}$ & $\begin{array}{c}\mathbf{C u} \\
\mathbf{p p m}\end{array}$ & $\begin{array}{c}\mathbf{Z n} \\
\mathbf{p p m}\end{array}$ & $\begin{array}{c}\mathbf{M n} \\
\mathbf{p p m}\end{array}$ & $\begin{array}{c}\text { Sand } \\
\mathbf{\%}\end{array}$ & $\begin{array}{c}\text { Clay } \\
\mathbf{\%}\end{array}$ & $\begin{array}{c}\text { Silt } \\
\mathbf{\%}\end{array}$ & Texture \\
\hline 6.87 & 0.602 & 0.64 & 0.90 & 1.67 & 114 & 13.01 & 1.78 & 0.60 & 21.89 & 41.64 & 51.32 & 7.04 & $\mathrm{~L}$ \\
\hline
\end{tabular}




\section{Methods}

\section{Experimentation}

The study was carried out in Field Crops Department Laboratory of Faculty of Agriculture Siirt University in Turkey, on factorial design in randomized plots with 3 replications first factor is bacteria application with 6 strains and control level. Second factor was salt concentration with 5 levels. According to the experiment design, there were 3 plants in each pot. Pots used in experiment top diameter: $16.5 \mathrm{~cm}$, base diameter $12.5 \mathrm{~cm}$, height $14 \mathrm{~cm}$ and volume 2.11 features.

The study was carried out under the conditions of $20-24{ }^{\circ} \mathrm{C}$ (daily) and $70-50 \%$ (daily) humidity. The light was programmed to be $16 / 8 \mathrm{~h}$ light/dark.

\section{Fertilizer application}

As control treatment, $200 \mathrm{mg} \mathrm{N} / \mathrm{kg}, 60 \mathrm{mg} \mathrm{P}_{2} \mathrm{O}_{5} / \mathrm{kg}$ doses were applied for standard fertilization in $1 \mathrm{~kg}$ pots (Alpaslan et al., 1998).

\section{Salt concentrations}

Soil salinity and salinity stress usually refers to $\mathrm{NaCl}$ (Tort and Türkyılmaz, 2003). Thus, only $\mathrm{NaCl}$ was used to create salinity stress. In order to create salinity stress in germination medium, $0,50,75,100$ and $125 \mathrm{mM} \mathrm{NaCl}$ solutions were applied to the pot soil under field conditions in line with Tüzüner (1990) to create unsalty, slightly salty, salty, very salty and too salty levels, respectively.

\section{Bacterial treatment}

In the experiments, bacteria isolated from Van Lake Basin, which are already identified via microbial identification system (MIS) and which have proven PGPR activity under greenhouse and field conditions, were used. The bacteria were cultured in liquid medium and encoded to the seeds. Nutrient broth (NB) and ASHBY medium were used as liquid media for bacteria cultures. The nutrient media was sterilized at $121{ }^{\circ} \mathrm{C}$ in autoclave and transferred from solid nutrient medium to the liquid nutrient medium in the sterilized container. The bacteria transferred to the liquid medium were incubated in the shaker at $26 \pm 2{ }^{\circ} \mathrm{C}$ for $2 \mathrm{~h}$. The cultured bacteria were applied to the seeds in $10^{8} \mathrm{cfu} / \mathrm{ml}$ concentration (Clark, 1965).

\section{Obtaining the data}

The experiment was continued for 6 weeks and following observations and measurements were made in accordance with the methods used by other researchers (Sehirali, 1989; Steiner et al., 1989; K1rtok et al., 1994).

Germination rate (\%): the number of seeds germinated in the first four days is determined and calculated as percentage. In order to investigate the effect of wheat on germination rate, the rate of germination was obtained at the end of forth days.

Germination percentage (\%): the percentage of germinated seeds at the end of the $8^{\text {th }}$ day of germination is determined. In order to determine the number of germinated seeds with the application of salt and bacteria, the percentage of germination was determined on the $8^{\text {th }}$ day.

At the end of the $6^{\text {th }}$ week: 
Plant length $(\mathrm{cm})$ : the distance from the crown to the end of the flag leaf was measured in $\mathrm{cm}$ in each plant before the harvest and the average plant length was calculated.

Root length $(\mathrm{cm})$ : after the harvest, root of each plant was measured. The longest root was measured in each plant and the root length was found in $\mathrm{cm}$.

Plant wet weight $(g)$ : the plants were dried and weighted after being harvested and their roots are cleared from soil.

Plant dry weight $(g)$ : the plants were dried in the oven at $65^{\circ} \mathrm{C}$ until a fixed weight and weighted.

Nitrogen and phosphorus amount in the soil (\%): Nitrogen and phosphorus content of the soil was measured after the harvest according to Kacar (1984).

The study was established to determine the effect of salt and PGPR applications during the first development period of the plant. Therefore, the experiment was ended at the end of the first development period of 6 weeks. Similar studies have been followed in previous studies (Moxley et al., 1978; Timm et al., 1991; Al et al., 2004).

\section{Statistical analysis of the results}

Statistical calculations were done in Costat and SPSS software in accordance with the experiment plan. The differences between the averages were determined using Duncan test.

\section{Results}

In this study, bacterial treatments were done in pot soils with different $\mathrm{NaCl}$ concentrations $(0,50,75,100$ and $125 \mathrm{mM})$ to reduce salinity stress for the plants cultivated in these pots and yield parameters are measured after 42 days development period. While the bacteria treatment group was not fertilized, the control group was fertilized at the normal doze $\left(200 \mathrm{mg} \mathrm{N} / \mathrm{kg}, 60 \mathrm{mg} \mathrm{P}_{2} \mathrm{O}_{5} / \mathrm{kg}\right)$ and no bacterial treatment was done.

\section{Germination rate}

The highest germination rate value in bacterial treatments was obtained as 95.33\% in B. atrophaeus + Bacillus-GC group treatment at the same time give closely values in, $84.33 \%$ for $K$. cryocrescens, $83.67 \%$ for Bacillus-GC group and Control, $79.33 \%$ C. turbata and $78.67 \%$ for $S$. maltophilia, while the lowest germination rate was obtained as $70.33 \%$ for $B$. atrophaeus bacterial treatments (Table 2).

In general, it was observed that the germination rate obtained from the salt applications was different and the differences between the values were significant. The germination rate in $0,50,75,100$ and $125 \mathrm{mM}$ dosages of salt concentrations were measured as $94.29,87.38,81.91,79.05$ and $68.33 \%$, respectively, and these figures were recorded as germination rates. The highest germination rate was obtained as $94.29 \%$ in $0 \mathrm{mM}$ salt concentration, while the lowest germination rate was obtained as $68.33 \%$ in $125 \mathrm{mM}$ treatment (Table 3).

In general, it was observed that the germination rate obtained from bacterial and salt treatments was found statistically significant. 
Table 2. Duncan test results for obtaining the data in Ceyhan 99 wheat species inoculated with different bacteria strains

\begin{tabular}{|c|c|c|c|c|c|c|c|c|}
\hline \multirow[b]{2}{*}{ Bacterial treatments } & \multicolumn{8}{|c|}{ Obtaining the Data } \\
\hline & $\begin{array}{c}\text { Germination } \\
\text { rate }(\%)^{*}\end{array}$ & $\begin{array}{c}\text { Germination } \\
\text { percentage } \\
(\%) \mathrm{ns}\end{array}$ & $\begin{array}{c}\text { Plant } \\
\text { height } \\
(\mathrm{cm})^{*}\end{array}$ & $\begin{array}{c}\text { Root } \\
\text { length } \\
(\mathrm{cm}) * *\end{array}$ & $\begin{array}{c}\text { Plant } \\
\text { wet } \\
\text { weight } \\
(\mathrm{g})^{*}\end{array}$ & $\begin{array}{c}\text { Plant } \\
\text { dry } \\
\text { weight } \\
(g)^{*}\end{array}$ & $\begin{array}{c}\text { Nitrogen } \\
\text { amount } \\
(\%)^{* * * *}\end{array}$ & $\begin{array}{c}\text { Phosphorus } \\
\text { amount } \\
(\%)^{*}\end{array}$ \\
\hline Control & $83.67^{\mathrm{b}}$ & 100.0 & $25.98^{\mathrm{a}}$ & $24.53^{\mathrm{abc}}$ & $0.309^{\mathrm{a}}$ & $0.036^{\mathrm{a}}$ & $0.052^{\mathrm{a}}$ & $5.401^{\mathrm{a}}$ \\
\hline $\begin{array}{l}\text { Stenotrophpmonas } \\
\text { maltophilia } \mathrm{P}\end{array}$ & $78.67^{\mathrm{bc}}$ & 99.3 & $24.79^{\mathrm{ab}}$ & $26.08^{\mathrm{a}}$ & $0.300^{\mathrm{a}}$ & $0.033^{\mathrm{ab}}$ & $0.048^{\mathrm{c}}$ & $4.928^{c}$ \\
\hline Bacillus-GC group P & $83.67^{\mathrm{b}}$ & 100.0 & $25.20^{\mathrm{ab}}$ & $25.07^{\mathrm{abc}}$ & $0.263^{\mathrm{b}}$ & $0.028^{\mathrm{b}}$ & $0.052^{\mathrm{b}}$ & $5.024^{\mathrm{b}}$ \\
\hline Bacillus atrophaeus $\mathrm{N}$ & $70.33^{\mathrm{c}}$ & 100.0 & $24.33^{\mathrm{b}}$ & $25.19^{\mathrm{ab}}$ & $0.250^{\mathrm{bc}}$ & $0.023^{\mathrm{c}}$ & $0.052^{\mathrm{a}}$ & $4.539^{\mathrm{e}}$ \\
\hline Cellulomonas turbata $\mathrm{N}$ & $79.33^{\mathrm{bc}}$ & 100.0 & $24.67^{\mathrm{b}}$ & $24.09^{\mathrm{bcd}}$ & $0.215^{\mathrm{cd}}$ & $0.017^{\mathrm{d}}$ & $0.051^{\mathrm{ab}}$ & $4.732^{\mathrm{d}}$ \\
\hline $\begin{array}{c}\text { Kluyvera cryocrescens } \\
\text { NP }\end{array}$ & $84.33^{\mathrm{b}}$ & 99.7 & $23.41^{\mathrm{b}}$ & $22.91^{\mathrm{d}}$ & $0.205^{\mathrm{d}}$ & $0.016^{\mathrm{d}}$ & $0.050^{\mathrm{b}}$ & $4.911^{\mathrm{c}}$ \\
\hline $\begin{array}{l}\text { Bacillus atrophaeus }+ \\
\text { Bacillus-GC group NP }\end{array}$ & $95.33^{\mathrm{a}}$ & 100.0 & $25.33^{\mathrm{ab}}$ & $23.52^{\mathrm{cd}}$ & $0.178^{\mathrm{d}}$ & $0.015^{\mathrm{d}}$ & $0.052^{\mathrm{a}}$ & $4.722^{\mathrm{d}}$ \\
\hline Avarages & 82.19 & 99.9 & 24.82 & 24.48 & 0.246 & 0.024 & 0.051 & 4.894 \\
\hline
\end{tabular}

$* * * \mathrm{P}<0.001 ; * * \mathrm{P}<0.01 ; * \mathrm{P}<0.05 ;$ ns non-significant

Table 3. Duncan test results for obtaining the data in Ceyhan 99 wheat species with different salt concentrations

\begin{tabular}{|c|c|c|c|c|c|c|c|c|}
\hline \multirow[b]{2}{*}{$\begin{array}{c}\text { Salt } \\
\text { concentrations }\end{array}$} & \multicolumn{8}{|c|}{ Obtaining the Data } \\
\hline & $\begin{array}{c}\text { Germination } \\
\text { rate }(\%)^{* * *}\end{array}$ & $\begin{array}{c}\text { Germination } \\
\text { percentage } \\
(\%)^{\mathrm{ns}}\end{array}$ & $\begin{array}{c}\text { Plant } \\
\text { height } \\
(\mathrm{cm})^{\mathrm{ns}}\end{array}$ & $\begin{array}{c}\text { Root } \\
\text { length } \\
(\mathrm{cm})^{*}\end{array}$ & $\begin{array}{c}\text { Plant } \\
\text { wet } \\
\text { weight } \\
(g)^{*}\end{array}$ & $\begin{array}{c}\text { Plant } \\
\text { dry } \\
\text { weight } \\
(\mathrm{g})^{*} \\
\end{array}$ & $\begin{array}{l}\text { Nitrogen } \\
\text { amount } \\
(\%)^{* * *}\end{array}$ & $\begin{array}{c}\text { Phosphorus } \\
\text { amount } \\
(\%)^{*}\end{array}$ \\
\hline $0 \mathrm{mM}$ & $94.29^{\mathrm{a}}$ & 99.52 & 25.38 & $24.38^{\mathrm{ab}}$ & $0.268^{\mathrm{a}}$ & $0.020^{\mathrm{b}}$ & $0.054^{\mathrm{a}}$ & $5.094^{\mathrm{a}}$ \\
\hline $50 \mathrm{mM}$ & $87.38^{\mathrm{b}}$ & 99.76 & 25.26 & $25.59^{\mathrm{a}}$ & $0.258^{\mathrm{ab}}$ & $0.024^{\mathrm{ab}}$ & $0.053^{\mathrm{ab}}$ & $4.826^{\mathrm{d}}$ \\
\hline $75 \mathrm{mM}$ & $81.91^{\mathrm{cd}}$ & 100.00 & 24.37 & $24.61^{\mathrm{ab}}$ & $0.221^{\mathrm{c}}$ & $0.024^{\mathrm{ab}}$ & $0.051^{\mathrm{cd}}$ & $4.931^{\mathrm{b}}$ \\
\hline $100 \mathrm{mM}$ & $79.05^{\mathrm{c}}$ & 100.00 & 24.24 & $24.26^{\mathrm{ab}}$ & $0.227^{\mathrm{bc}}$ & $0.026^{\mathrm{a}}$ & $0.050^{\mathrm{d}}$ & $4.908^{c}$ \\
\hline $125 \mathrm{mM}$ & $68.33^{\mathrm{d}}$ & 100.00 & 24.44 & $23.57^{\mathrm{c}}$ & $0.254^{\mathrm{ab}}$ & $0.027^{\mathrm{a}}$ & $0.052^{\mathrm{bc}}$ & $4.711^{\mathrm{e}}$ \\
\hline Avarages & 82.19 & 99.86 & 24.74 & 24.48 & 0.246 & 0.024 & 0.052 & 4.894 \\
\hline
\end{tabular}

$* * * \mathrm{P}<0.001 ; * * \mathrm{P}<0.01 ; * \mathrm{P}<0.05 ;$ ns non-significant

\section{Germination percentage}

The highest germination percentage value in bacterial treatments was obtained as $100 \%$ in B. atrophaeus + Bacillus-GC group, Bacillus-GC group, B. atrophaeus, $C$. turbata and Control treatments at the same time give closely values in, $99.7 \%$ for $K$. cryocrescens, while the lowest germination percentage was obtained as $99.3 \%$ for $S$. maltophilia bacterial treatments (Table 2).

In general, it was observed that the germination percentage obtained from the salt applications was close and the differences between the values were not significant. The germination percentage in $0,50,75,100$ and $125 \mathrm{mM}$ dosages of salt concentrations were measured as 99.52, 99.76, 100, 100 and 100\%, respectively, and these figures were recorded as germination percentage. The highest germination percentage was obtained as $100 \%$ in $75 \mathrm{mM}, 100 \mathrm{mM}$ and $125 \mathrm{mM}$ salt concentration, while the lowest germination percentage was obtained as $99.52 \%$ in $0 \mathrm{mM}$ treatment (Table 3). 
In general, it was observed that the germination percentage obtained from bacterial and salt treatments was found statistically not significant.

\section{Plant height}

The highest plant height value in bacterial treatments was obtained as $25.98 \mathrm{~cm}$ in control treatment at the same time give closely values in $25.33 \mathrm{~cm}$ for B. atrophaeus + Bacillus-GC group, $25.20 \mathrm{~cm}$ for Bacillus-GC group and 24.79 for S. maltophilia, while the lowest plant height was obtained as $23.41 \mathrm{~cm}$ for $K$. cryocrescens bacterial treatments (Table 2).

In general, it was observed that the plant height obtained from the salt applications was close and the differences between the values were not significant. The plant heights in $0,50,75,100$ and $125 \mathrm{mM}$ dosages of salt concentrations were measured as $25.38 \mathrm{~cm}, 25.26 \mathrm{~cm}, 24.37 \mathrm{~cm}, 24.24 \mathrm{~cm}$ and $24.44 \mathrm{~cm}$, respectively, and these figures were recorded as plant heights. The highest plant height was obtained as $25.38 \mathrm{~cm}$ in $0 \mathrm{mM}$ salt concentration, while the lowest plant height was obtained as $24.24 \mathrm{~cm}$ in $100 \mathrm{mM}$ treatment (Table 3).

In general, it was observed that the plant height obtained from the bacterial treatments were found statistically significant.

\section{Root length}

The highest root length value in bacterial treatments was obtained as $26.08 \mathrm{~cm}$ in $S$. maltophilia treatment besides other values in $25.19 \mathrm{~cm}$ for B. atrophaeus, $25.07 \mathrm{~cm}$ for Bacillus-GC group, 24.53 for Control treatment, $24.09 \mathrm{~cm}$ for C. turbata, $23.52 \mathrm{~cm}$ for B. atrophaeus + Bacillus-GC group while the lowest root length was obtained as $22.91 \mathrm{~cm}$ for $K$. cryocrescens bacterial treatments (Table 2).

It was observed that the root length obtained from the salt applications was close and the differences between the values were significant. The plant heights in $0,50,75,100$ and $125 \mathrm{mM}$ dosages of salt concentrations were measured as $24.38 \mathrm{~cm}, 25.59 \mathrm{~cm}$, $24.61 \mathrm{~cm}, 24.26 \mathrm{~cm}$ and $23.57 \mathrm{~cm}$, respectively, and these figures were recorded as root length. The highest root length was obtained as $25.59 \mathrm{~cm}$ in $50 \mathrm{mM}$ salt concentration, while the lowest root length was obtained as $23.57 \mathrm{~cm}$ in $125 \mathrm{mM}$ treatment (Table 3).

In general, it was observed that the root length obtained from bacterial and salt treatments was found statistically significant.

\section{Plant wet weight}

The highest plant wet weight value in bacterial treatments was obtained as $0.309 \mathrm{~g}$ in Control treatment at the same time give closely value in, $0.300 \mathrm{~g}$ for $S$. maltophilia, while the lowest plant wet weight was obtained as 0.178 for B. atrophaeus + BacillusGC group bacterial treatments (Table 2).

It was observed that the plant wet weight obtained from the salt applications was different and the differences between the values were significant. The plant wet weight in $0,50,75,100$ and $125 \mathrm{mM}$ dosages of salt concentrations were measured as $0.268 \mathrm{~g}$, $0.258 \mathrm{~g}, 0.221 \mathrm{~g}, 0.227 \mathrm{~g}$ and $0.254 \mathrm{~g}$, respectively, and these figures were recorded as plant wet weights. The highest plant wet weight was obtained as $0.268 \mathrm{~g}$ in $0 \mathrm{mM}$ salt concentration, while the lowest plant wet weight was obtained as $0.221 \mathrm{~g}$ in $75 \mathrm{mM}$ treatment (Table 3). 
In general, it was observed that the plant wet weight obtained from bacterial and salt treatments was found statistically significant.

\section{Plant dry weight}

The highest plant dry weight value in bacterial treatments was obtained as $0.036 \mathrm{~g}$ in Control treatment at the same time give closely value in, $0.033 \mathrm{~g}$ for $S$. maltophilia, while the lowest plant dry weight was obtained as $0.015 \mathrm{~g}$ for B. atrophaeus + BacillusGC group bacterial treatments (Table 2).

It was observed that the plant dry weight obtained from the salt applications was different and the differences between the values were significant. The plant dry weight in $0,50,75,100$ and $125 \mathrm{mM}$ dosages of salt concentrations were measured as $0.020 \mathrm{~g}$, $0.024 \mathrm{~g}, 0.024 \mathrm{~g}, 0.026 \mathrm{~g}$ and $0.027 \mathrm{~g}$, respectively, and these figures were recorded as plant dry weights. The highest plant dry weight was obtained as $0.027 \mathrm{~g}$ in $125 \mathrm{mM}$ salt concentration, while the lowest plant dry weight was obtained as $0.020 \mathrm{~g}$ in $0 \mathrm{mM}$ treatment (Table 3).

In general, it was observed that the plant dry weight obtained from bacterial and salt treatments was found statistically significant.

\section{Nitrogen amount in the soil}

The highest nitrogen amount in the soil was obtained in B. atrophaeus bacterial treatment (Table 4). Close figures were obtained in terms of the nitrogen amount in the soil in the other bacterial treatments which were control group and Bacillus atrophaeus + Bacillus-GC group NP. treatment.

Table 4. Duncan test results for amounts of nitrogen in Ceyhan 99 wheat species inoculated with different bacteria strains in different salt concentrations

\begin{tabular}{|c|c|c|c|c|c|c|}
\hline \multicolumn{7}{|c|}{ Nitrogen amounts* } \\
\hline \multirow{2}{*}{ Bacteria treatments } & \multicolumn{5}{|c|}{ Salt concentration } & \multirow{2}{*}{ Avarages } \\
\hline & $\mathbf{0} \mathbf{~ m M}$ & $50 \mathrm{mM}$ & $75 \mathrm{mM}$ & $100 \mathrm{mM}$ & $125 \mathrm{mM}$ & \\
\hline Control & $0.051^{\mathrm{c}-\mathrm{g}}$ & $0.053^{b-f}$ & $0.053^{b-f}$ & $0.054^{\mathrm{a}-\mathrm{d}}$ & $0.050^{\mathrm{d}-\mathrm{g}}$ & $0.0522^{\mathrm{A}}$ \\
\hline Stenotrophpmonas maltophilia $\mathrm{P}$ & $0.055^{\mathrm{a}-\mathrm{e}}$ & $0.048^{\mathrm{gh}}$ & $0.050^{\mathrm{c}-\mathrm{g}}$ & $0.037^{1}$ & $0.050^{\mathrm{d}-\mathrm{g}}$ & $0.0480^{\mathrm{C}}$ \\
\hline Bacillus-GC group NP & $0.055^{\mathrm{b}-\mathrm{g}}$ & $0.053^{\mathrm{b}-\mathrm{g}}$ & $0.049^{\text {efg }}$ & $0.049^{\text {efg }}$ & $0.053^{\mathrm{b}-\mathrm{f}}$ & $0.0518^{\mathrm{B}}$ \\
\hline Bacillus atrophaeus $\mathrm{N}$ & $0.052^{\mathrm{b}-\mathrm{g}}$ & $0.054^{\mathrm{a}-\mathrm{e}}$ & $0.051^{\mathrm{c}-\mathrm{g}}$ & $0.050^{\mathrm{d}-\mathrm{g}}$ & $0.055^{\mathrm{a}-\mathrm{e}}$ & $0.0524^{\mathrm{A}}$ \\
\hline Cellulomonas turbata $\mathrm{N}$ & 0.049 efg & $0.053^{b-f}$ & 0.049 efg & $0.053^{b-f}$ & $0.052^{\mathrm{b}-\mathrm{g}}$ & $0.0512^{\mathrm{AB}}$ \\
\hline Kluyvera cryocrescens NP & $0.054^{\mathrm{a}-\mathrm{e}}$ & $0.050^{\mathrm{c}-\mathrm{g}}$ & $0.051^{\mathrm{c}-\mathrm{g}}$ & $0.051^{\mathrm{c}-\mathrm{g}}$ & $0.045^{\mathrm{h}}$ & $0.0502^{\mathrm{B}}$ \\
\hline $\begin{array}{c}\text { Bacillus atrophaeus }+ \text { Bacillus-GC group } \\
\mathrm{NP}\end{array}$ & $0.051^{\mathrm{c}-\mathrm{g}}$ & $0.051^{\mathrm{c}-\mathrm{g}}$ & $0.050^{\mathrm{d}-\mathrm{g}}$ & $0.057^{\mathrm{a}}$ & $0.052^{\mathrm{b}-\mathrm{g}}$ & $0.0522^{\mathrm{A}}$ \\
\hline Avarages & $0.054^{\mathrm{A}}$ & $0.053 \mathrm{AB}$ & $0.051^{\mathrm{CD}}$ & $0.050^{\mathrm{D}}$ & $0.052^{\mathrm{BC}}$ & \\
\hline
\end{tabular}

*The statistical analysis was done at $\mathrm{p}<0.05$ significance level and different letters indicate statistically significant treatments 


\section{Phosphorus amount in the soil}

The highest phosphorus amount in the soil was measured in the control group and phosphorus figures were obtained differently in bacterial treatments (Table 5).

Table 5. Duncan test results for amount of phosphorus in Ceyhan 99 wheat species inoculated with different bacteria strains in different salt concentrations

\begin{tabular}{|c|c|c|c|c|c|c|}
\hline \multicolumn{7}{|c|}{ Phosphorus amounts $* * *$} \\
\hline \multirow{2}{*}{ Bacteria treatments } & \multicolumn{5}{|c|}{ Salt concentrations } & \multirow{2}{*}{ Avarages } \\
\hline & $\mathbf{0 ~ m M}$ & $50 \mathrm{mM}$ & $75 \mathrm{mM}$ & $100 \mathrm{mM}$ & $125 \mathrm{mM}$ & \\
\hline Control & 5.673 & 5.210 & 6.130 & 5.840 & 4.150 & $5.4007^{\mathrm{A}}$ \\
\hline Stenotrophpmonas maltophilia $\mathrm{P}$ & 5.170 & 5.670 & 4.470 & 4.580 & 4.750 & $4.9280^{\mathrm{C}}$ \\
\hline Bacillus-GC group NP & 4.310 & 4.120 & 5.573 & 5.917 & 5.200 & $5.0240^{\mathrm{B}}$ \\
\hline Bacillus atrophaeus $\mathrm{N}$ & 4.813 & 4.410 & 4.473 & 4.420 & 4.580 & $4.5393^{\mathrm{E}}$ \\
\hline Cellulomonas turbata $\mathrm{N}$ & 5.380 & 4.920 & 4.177 & 4.533 & 4.650 & $4.7320^{\mathrm{D}}$ \\
\hline Kluyvera cryocrescens NP & 5.560 & 4.703 & 4.930 & 4.417 & 4.943 & $4.9107^{\mathrm{C}}$ \\
\hline $\begin{array}{l}\text { Bacillus atrophaeus }+ \text { Bacillus-GC } \\
\text { group NP }\end{array}$ & 4.750 & 4.750 & 4.760 & 4.650 & 4.700 & $4.7220^{\mathrm{D}}$ \\
\hline Avarages & $5.0938^{\mathrm{A}}$ & $4.8262^{\mathrm{D}}$ & $4.9305^{\mathrm{B}}$ & $4.9081^{\mathrm{C}}$ & $4.7105^{\mathrm{E}}$ & \\
\hline
\end{tabular}

***The statistical analysis was done at $\mathrm{p}<0.001$ significance level and different letters indicate statistically significant treatments

\section{Discussion}

TV14B S. maltophilia $\mathrm{P}$ in $0 \mathrm{mM}$ salt concentration increased plant wet weight, nitrogen and phosphorus amounts in the soil and root length parameters. It was observed that this bacterium increased plant dry weight and the amount of phosphorus in the soil in $50 \mathrm{mM}$ salt concentration and increased root length in $75 \mathrm{mM}$ salt concentration.

It was observed that TV119E Bacillus-GC group P increased plant height, the amount of phosphorus in the soil and dry weight parameters in $100 \mathrm{mM}$.

It was determined that TV83D B. atrophaeus $\mathrm{N}$ bacteria increased root length and the amount of nitrogen in the soil in $0 \mathrm{mM}$ salt concentration and root length, phosphorus and nitrogen amounts in the soil in the control group in $125 \mathrm{mM}$ salt concentration.

TV54A C. turbata $\mathrm{N}$ bacterial treatment was found to provide increment in root length in $0 \mathrm{mM}$ salt concentration compared to the control group. In $125 \mathrm{mM}$ salt concentration, an increment in the amount of phosphorus and nitrogen in the soil was observed compared to the control treatment.

TV113C $K$. cryocrescens NP bacterial treatment increased the root length in $50 \mathrm{mM}$ salt concentration and increased the amount of phosphorus in the soil in $125 \mathrm{mM}$ salt concentration compared to the control treatment.

TV83D B. atrophaeus + TV119E Bacillus-GC group NP bacterial treatment was observed to increase germination rate and percentage parameters. An increase was observed in the amount of phosphorus in the soil in $125 \mathrm{mM}$ salt concentration and in the amount of nitrogen in the soil in $100 \mathrm{mM}$ salt concentration. 
Aliye et al. (2008) reported that B. subtilis strain increased the plant height and weight compared to the control group. It is reported by many researchers (Dokuyucu et al., 1997; Salantur, 2003; Şahin et al., 2004; Salantur et al., 2006; Çakmakçı et al., 2007; Naiman et al., 2009) that bacterial inoculation results in increment in the plant height. The results of this research are in line this finding.

Mayak et al. (2004) used Achromobacter piechaudii bacterium, which is isolated from plant root rhizosphere and carries ACC deaminase enzyme, in their study in Israel. The results of the study showed that this bacterium increased wet and dry weights in tomato seedlings in the presence of $\mathrm{NaCl}$ over $172 \mathrm{mM}$.

Jalili et al. (2009) observed an increase in germination of canola seeds under salt stress with PGPR bacterial inoculation, containing ACC deaminase. The findings in our study are similar to those of the researchers.

Çakmakçı et al. (2007), used Bacillus OSU-142, Panibacillus polymyxa, Bacillus megaterium, Bacillus M-13, Bacillus licheniformis, Pseudomonas putida and Rhodobacter capsulatus isolates, which can fixate nitrogen, for the development of barley. The researchers reported that some of these isolates can produce indole acetic acid, while some others can solubilize phosphate; and they obtained 28.8 to $54.2 \%$ increment in body weight and 17.9 to $32.1 \%$ increment in root length. Furthermore, they stated that inoculation of phosphorus solubilizing bacteria is beneficial for the uptake of nitrogen, iron, manganese and copper by the plant.

Soil analysis is done after the harvest and the highest nitrogen amount was obtained in TV83D B. atrophaeus $\mathrm{N}$ bacterial treatment. It was observed that bacterial treatments without fertilizer increased the nitrogen amount in the soil, thus it can be resulted that these bacterial treatments help nitrogen fixation. The amount of nitrogen in the soil measured in the control treatment with inorganic fertilization is close to the bacterial treatments. It can be concluded from Table 4 that the nitrogen amount accumulated in the soil decreases as the salt concentration increases.

According to soil analysis results, the highest amount of phosphorus was obtained in the control treatment. Bacterial treatments without fertilizer have shown to increase the amount of phosphorus in the soil, which can be concluded as these bacteria can solubilize phosphorus. The amount of nitrogen in the soil measured in the control treatment with inorganic fertilization is close to the bacterial treatments. It can be concluded from Table 5 that the phosphorus amount accumulated in the soil decreases as the salt concentration increases.

Previous studies showed that PGPRs have different mechanisms such as fixating free nitrogen in the air (Çakmakçı et al., 2007), and solubilizing inorganic phosphate sources (Aslantaş et al., 2007). The results obtained in this research are similar to those findings.

\section{Conclusion}

As a result, it is thought that TV14B S. maltophilia strain can be an alternative to fertilization in the soil without salinity stress and reduce the problems encountered. On the other hand, TV119E Bacillus-GC group strain is thought to alleviate the challenges faced in wheat farming especially in the saline soils.

Furthermore, TV113C K. cryocrescens, TV83D B. atrophaeus, TV54A C. turbata and TV83D B. atrophaeus + TV119E Bacillus-GC group bacterial treatments are thought to reduce the adverse effects of salinity stress and increase the nitrogen and phosphorus amounts in the soil. 
Selected strains showed good phosphate solubilizing and nitrogen fixing ability. A pot experiment in a greenhouse was conducted in order to investigate the effect of different phosphate solubilizing and nitrogen fixing bacterial species on wheat.

In this study, the bacteria, which have been studied in the laboratory and field conditions, were inoculated. These bacteria have been isolated from their natural environment and have not been studied before. With this result, it is aimed to create a new alternative which cannot be polluting the environment and can be used in sustainable and organic agriculture.

Acknowledgements. This study is Ms. thesis and is supported with the project no 2016- SİÜFE-24 by Siirt University Coordinator of Scientific Research and Projects.

\section{REFERENCES}

[1] Abdel, M., Khalba, M., Abdel-Kliakk, H. M. A., Abdel-Ghani. M. L. (1997): Adverse Environmental of N Fertilizer Abuse. - M. Egypl. Bio-Organik Farming System for Sustainable Agriculture, 20 November-6 December, 1995, Cairo, pp. 50-57.

[2] Al, I., Dong, Y, Triplett, E. W. (2004): Nitrogen fixation in wheat provided by Klebsiella pneumoniae 342. - Mol. Plant Microbe Interact. 17: 1078-1085.

[3] Aliye, N., Fininsa, C., Hiskias, Y. (2008): Evaluation of rhizosphere bacterial antagonists for their potential to bioprotect potato (Solanum tuberosum) against bacterial wilt (Ralstonia solanacearum). - Biological Control 47: 282-288.

[4] Alpaslan, M., Güneş, A., İnal, A. (1998): Deneme Tekniği. - Ankara Üniversitesi Ziraat Fakültesi, Yayın No: 1501, Ders Kitabi 455, Ankara.

[5] Ansari, F. A., Ahmad, I. (2018): Biofilm development, plant growth promoting traits and rhizosphere colonization by Pseudomonas entomophila FAP1: A promising PGPR. Adv. Microbiol. 8(3): 235.

[6] Aslantaş, R., Çakmakçı, R., Şahın, F. (2007): Effect of plant growth promoting rhizobacteria on young apple tree growth and fruit yield under orchard conditions. Scientia Horticulturae 111: 371-377.

[7] Aydeniz, A. (1992): Gübreleme ekonomi ilişkileri. - II. Ulusal Gübre Kongresi Tebliğleri, 30 Eylül-4 Ekim, 1991, Ankara, pp. 71-80.

[8] Çakmakçı, R., Dönmez, M. F., Erdoğan, Ü. (2007): The effect of plant growth promoting rhizobacteria on barley, seedling growth, nutrient uptake, some soil properties and bacterial counts. - Turkish Journal of Agriculture and Forestry 31: 189-199.

[9] Canbolat, M., Bilen, S., Çakmakçı, R., Şahin, F., Aydın, A. (2006): Effect of plant growth promoting rhizobacteria and soil compaction on barley seedling growth, nutrient uptake, soil properties and rhizosphere microflora. - Biology and Fertility of Soils 42: 350-357.

[10] Chen, Y., Mei, R., Lu, S., Liu, L., Kloepper, J. W. (1996): The Use of Yield Increasing Bacteria (YIB) as Plant Growth Promoting Rhizobacteria in Chinese Agriculture. - In: Uthkede, R. S., Gupta, W. K. (eds.) Management of Soil Borne Diseases. Kalyani Publishers, Ludhiana, pp. 164-184.

[11] Clark, F. E. (1965): Aerobic Spore Forming Bacteria. - In: Black, C. A. et al. (eds). Methods of Soil Analysis, Part 2. American Society of Agronomy, Madison, WI, pp. 1473-1476.

[12] Dey, R., Pal, K. K., Bhatt, D. M., Chauhan, S. M. (2004): Growth promotion and yield 90 enhancement of peanut (Arachis hypogaea L.) by application of plant growth promoting rhizobacteria. - Microbiological Research 159: 371-394.

[13] Dokuyucu, T., Akkaya, A., Kırtok, Y. (1997): Bakteri aşılamasının (Azospirillum brasiliense Sp246) ekmeklik buğday (Triticum aestivum L.) çesidi Gemini'nin verim 
unsurları üzerine etkisi. - Türkiye II. Tarla Bitkileri Kongresi, 22-25 Eylül 1997, Samsun, pp. 56-60.

[14] García De Salamone, I. E., Hynes, R. K., Nelson, L. M. (2001): Cytokinin production by plant growth promoting rhizobacteria and selected mutants. - Canadian Journal of Microbiology 47: 404-411.

[15] Glick, B. R., Karaturovíc, D. M., Newell, P. C. (1995): A novel procedure for rapid isolation of plant growth promoting pseudomonads. - Canadian Journal of Microbiology 41: 533-536.

[16] Gutiérrez-Mañero, F. J., Ramos-Solano, B., Probanza, A., Mehouachi, J., Tadeo, F. R., Talon, M. (2001): The plant-growth-promoting rhizobacteria Bacillus pumilus and Bacillus licheniformis produce high amounts of physiologically active gibberellins. Physiologia Plantarum 111: 206-211.

[17] Guttman, B. S. (1999): Biology. - WCB/McGraw-Hill, Iowa. Boston.

[18] Hashem, A., Abd Allah, E. F., Alqarawi, A. A., Al-Huqail, A. A., Wirth, S., Egamberdieva, D. (2016): The interaction between arbuscular mycorrhizal fungi and endophytic bacteria enhances plant growth of Acacia gerrardii under salt stress. - Front Microbiol. 7: 1089.

[19] Jalili, F., Khavazi, K., Pazira, E., Nejati, A. and Asadi Rahmani, H. (2009): Use of ACC deaminase -containing fluorescent pseudomonads to alleviate effects of salinity on canola (Brassica napus L.) growth in germination stage. - Iranian J. Soil Research (Soil Water Sci.) 23(1): 91-105.

[20] Jeon, J. S., Lee, S. S., Kim, H. Y., Ahn, T. S., Song, H. G. (2003): Plant growth promotion in soil by some inoculated microorganisms. - Journal of Microbiology 41: 271-276.

[21] Kacar, B. (1984): Bitki besleme uygulama klavuzu. - Ankara Üniversitesi Ziraat Fakültesi Yayınları, Ankara.

[22] Kirtok, Y. (1984): Tahıllarda biyolojik verim, hasat indeksi ve tane verimi. I. Tarımsal kriter olarak çevre koșullarından etkilenişleri. - Doğa Bilimleri Dergisi 8(1): 96-102.

[23] Luz, W. C. (2000): Plant growth promoting rhizobacteria in graminicolous crops in Brazil. - Fifth International PGPR Workshop, 29 October-3 November 2000, CordobaArgentina.

[24] Mayak, S., Tirosh, T., Glick, B. R. (2004): Plant growth-promoting bacteria that confer resistance to water stress in tomato and pepper. - Plant Sci. 166: 525-530.

[25] Moxley, M. G., Berg, W. A., Barrau, E. M. (1978): Salt tolerance of five varieties of wheatgrass during seedling growth. - Journal of Range Management 31(1): 54-55.

[26] Naiman, A. D., Latronico, A., Salamone, I. E. A. (2009): Inoculation of wheat with Azospirillum brasilense and Pseudomonas flourescens: impact on the production and culturable rhizosphere microflora. - European Journal of Soil Biology 45: 44-51.

[27] Narula, N., Kumar, V., Singh, B., Bhatıa, R., Lakshmınarayana, K. (2005): Impact of biofertilizers on grain yield in spring wheat under varying fertility conditions and wheatcotton rotation. - Archives of Agronomy and Soil Science 51(1): 79-89.

[28] Öztürk, A., Çağlar, Ö., Sahin, F. (2003): Yield response of wheat and barley to inoculation of plant growth promoting rhizobacteria at various levels of nitrogen fertilization. - J. Plant Nutrition Soil Science 166: 262-266.

[29] Romerio, R. S. (2000): Preliminary results on PGPR research at the Universidade Federal de Viçosa, Brazil. - Fifth International PGPR Workshop, 29 October-3 November 2000, Cordoba-Argentina.

[30] Sabır, A. (2013): Improvement of grafting efficiency in hard grafting grape berlandieri hybrid rootstocks by plant growth-promoting rhizobacteria (PGPR). - Scientia Horticulturae 164(5): 24-29.

[31] Salantur, A. (2003): Erzurum Pasinler Ovalarındaki Buğdaygil Bitkilerinin Yetiştiği Topraklardan İzole Edilen Asimbiyotik Bakteri Suşlarının Buğday ve Arpada Gelişme ve 
Verim Üzerine Etkileri (Doktora Tezi, Basılmamış). Atatürk Üniversitesi Fen Bilimleri Enstitüsü, Erzurum.

[32] Salantur, A., Ozturk, A., Akten, S. (2006): Growth and yield response of spring wheat (Triticum aestivum L.) to inoculation with rhizobacteria. - Plant Soil Environment 52(3): 111-118.

[33] Shrivastava, P., Kumar, R. (2018): Soil salinity: a serious environmental issue and plant growth promoting bacteria as one of the tools for its alleviation. - Saudi. J. Biol. Sci. 22(2): 123-131.

[34] Steiner, J. J., Grabe, D. F., Tulo, M. (1989): Single and multiple vigor tests for predicting seedling emergence of wheat. - Crop Sci. 29: 782-786.

[35] Şahin, F., Çakmakçı, R., Kantar, F. (2004): Sugar beet and barley yields in relation to inoculation with N2-fixing and phosphate solubilizing bacteria. - Plant Soil 265: 123129.

[36] Şehirali, S. (1989): Tohumluk ve teknolojisi. - Güneş Tohumculuk Yayınları, Ankara.

[37] Timm, D. A., Waskom, R. M., Miller, D. R., Nabors, M. W. (1991): Greenhouse evaluation of regenerated spring wheat for enhanced salt tolerance. - Cereal Research Communications 19(4): 451-457.

[38] Tort, N., Türky1lmaz, B. (2003): Physiological effects of $\mathrm{NaCl}$ on two barley (Hordeum vulgare L.) cultivars. - Turkish Journal of Field Crops 8: 68-75.

[39] Tüzüner, A. (1990): Toprak ve su analiz laboratuarları el kitabı. - Mülga KHGM Yayınlar1, Ankara.

[40] Upadhyay, S. K., Singh, J. S., Saxena, A., Singh, D. P. (2014): Impact of PGPR inoculation on growth and antioxidants status of wheat plant under saline condition. Plant Biol. 14: 605-611.

[41] Wall, L. G. (2000): Consequences of an Overview on PGPR Work in Argentina: The Field Should Be Wider. - Fifth International PGPR Workshop, 29 October-3 November 2000, Cordoba-Argentina. 